\title{
FRANZ BOAS OG DET MODERNE ETNOGRAFISKE MUSEUMS (U)MULIGHED
}

\author{
ANNA KAAE KJÆERGAARD
}

Franz Boas (1858-1942) er en af det 20. århundredes mest betydningsfulde antropologer. Han har haft en enorm indflydelse på udviklingen af den kulturrelativistiske tænkning, der ligger til grund for den moderne antropologi, samt på indførelsen af feltstudiet som antropologiens videnskabelige metode par excellence. Han var gennem en lang årrække en af nøglepersonerne i American Anthropological Association og bidrog i 1905 til etableringen af det første ph.d.program i antropologi i USA, hvor han de efterfølgende årtier ,opfostrede“ nogle af de unge talenter, der sidenhen blev store navne inden for antropologien, blandt andre Ruth Benedict, Margaret Mead, Robert Lowie og Alfred L. Kroeber. Han er samtidig kendt for sit store engagement i kampen mod racismen i USA i 1910'erne og -20'erne og senere også mod nazismen, som han op gennem 30'erne og 40'erne åbent kritiserede.

Hvad der er mindre kendt i dag, er imidlertid, at Boas begyndte sin akademiske karriere inden for museumsverdenen, hvor han fungerede som kurator ved forskellige museer i næsten 30 år, inden han 1905 skiftede definitivt over til universitetet. Det var netop via sit engagement i museumsfaglige diskussioner, at han for første gang formulerede nogle af de kulturteorier, som senere skulle gøre ham internationalt anerkendt som den moderne antropologis fader. Når denne side af historien er så underbelyst, hænger det sammen med, at den videnskabelige antropologi i dag først og fremmest er en universitetsdisciplin, hvorimod den tilbage i 1880 'erne, hvor Boas begyndte sit virke, var centreret omkring de etnografiske museer og etnografiske museumsafdelinger på naturhistoriske museer. Antropologiens institutionelle skift fra museet til universitetet er, som William C. Sturtevant har påpeget, ikke noget pludseligt, absolut brud, men en grad- og delvis overgang, der netop tager sin begyndelse i 1880 ' erne, men først kulminerer i 1920'erne (Sturtevant 1969). Sturtevant inddeler antropologiens historie i tre perioder: en museumsperiode (1840-90), en museums-universitets-periode (1890- 
1920) og en universitetsperiode (1920-) (ibid.). Og det er netop i overgangsfasen mellem de to sidste perioder, at Boas spiller en helt central rolle. For selvom den kulturrelativistiske tænkning, han er med til at udvikle, tager udgangspunkt i en museumsfaglig kontekst, medfører denne tænknings udbredelse i begyndelsen af det 20. århundrede paradoksalt nok netop, at antropologien flytter fra museet til universitetet.

Jeg vil i det følgende se nærmere på to museumsfaglige debatter, som Boas indgik i, nemlig debatten i 1887 med den ledende kurator ved United States National Museum, Otis T. Mason, og debatten i 1907 med kurator for den antropologiske afdeling af Field Museum of Natural History, George A. Dorsey. Disse to diskussioner spejler på flere måder hinanden og kan tilsammen siges at være en gennemspilning af antropologiens historie en miniature. Diskussionen med Mason foregår i samme periode, som Boas påbegynder sin karriere inden for museumsverdenen. Han er emigreret til USA fra Tyskland året forinden og er blevet ansat som redaktionsassistent på tidsskriftet Science sideløbende med en deltidsstilling som docent ved Afdeling for Psykologi ved Clark University. Med i bagagen har han samtidig et års erfaring som assisterende kurator for Adolf Bastian ved Museum für Völkerkunde i Berlin, hvor han arbejdede 1885-86. I polemikken mod Mason kritiserer Boas den traditionelle typologiske udstillingsform, som dominerer samtidens evolutionistisk orienterede etnografiske museer og museumsafdelinger, og han skitserer samtidig for første gang ideerne til en moderne etnografisk udstillingsform, som modsvarer hans egen gryende kulturrelativistiske tænkning (Boas 1887a, 1887b).

Diskussionen med Dorsey finder omvendt sted to år efter, at Boas definitivt har forladt museumsverdenen til fordel for universitetet. Han har på dette tidspunkt adskillige års erfaring inden for museumsverdenen og har haft rig lejlighed til at afprøve sine ideer i praksis. I 1892 bliver han udpeget som assisterende kurator for Frederic Ward Putnam ved Verdensudstillingen i Chicago, hvor han blandt andet arrangerer liveoptrædener med kwakiutlgrupper fra British Columbia. Efter udstillingen arbejder han nogle måneder ved Field Museum, inden han i 1896 bliver fastansat som kuratorassistent for Putnam, der i mellemtiden er blevet leder af Afdeling for Etnologi og Somatologi ved American Museum of Natural History (AMNH), som senere blev omdøbt til Afdeling for Antropologi. Trods en relativt succesfuld implementering af sine udstillingsprincipper på AMNH vælger Boas i 1905 at forlade museet og bliver i stedet ansat som professor i antropologi ved University of Columbia, hvor han siden sin ansættelse ved AMNH i 1896 har haft en deltidsstilling som lektor. Årsagen til dette karriereskift eksponeres indirekte i diskussionen med Dorsey, hvor Boas påpeger en række indbyggede begrænsninger i den selv samme udstillingsform, som han plæderede for 20 år 
forinden i polemikken mod Mason. Han giver i samme diskussionsindlæg også udtryk for en grundlæggende skepsis over for den antagelse om, at kulturer kan repræsenteres via deres materielle frembringelser, som per definition ligger til grund for det etnografiske museum (Boas 1907).

Det interessante ved disse to diskussioner er, at de ikke kun indrammer Boas' tid inden for museumsverdenen, men også belyser et helt centralt vendepunkt i antropologiens historie. Diskussionen med Mason er en af de tidsligste, mest skarpt optegnede formuleringer af principperne for en ny kulturelt kontekstualiserende kurateringspraksis, som senere under indflydelse fra Boas skulle blive det moderne etnografiske museums udstillingsform par excellence. Den markerer samtidig et generelt teoretisk skift inden for antropologien fra en evolutionistisk kulturtænkning, hvor samtidens mange forskellige samfund opfattes som befindende sig på hver deres stadie i samme globale kulturhistoriske udvikling, til en relativistisk kulturtænkning, hvor den kulturhistoriske udvikling opfattes som udspaltet i flere sidestillede, selvstændige forløb. Dette teoretiske skift afføder også et metodisk skift fra en rent spekulativ, deduktiv „lænestolsantropologi“ til en empirisk, induktiv videnskab baseret på længerevarende feltstudier. I sin diskussion med Dorsey eksponerer Boas den kulturrelativistiske tænknings grundlæggende uforenelighed med det etnografiske museum og dets indbyggede fokusering på den materielle side af kulturerne (ibid.). Han fastslår samtidig, at museets rolle først og fremmest er formidling, ikke forskning. Han foregriber dermed den videnskabelige antropologis institutionelle skift fra museet til universitetet, som blandt andet på grund af kulturrelativismens indtog blev en realitet 15-20 år senere.

De problematikker, som Boas optegner i sine museumskritiske artikler, er imidlertid ikke løst ved at flytte antropologien fra museet til universitetet eller erstatte den klassiske „lænestolsantropologi“ med feltstudiet. De peger nemlig ikke kun på en række indbyggede begrænsninger i det etnografiske museum som institution, men også i antropologien som helhed, begrænsninger, som stadig er højst aktuelle i antropologiske debatter i dag. Jeg vil afslutningsvis fremdrage to illustrative eksempler på, hvordan de problemstillinger, som Boas rejste omkring forrige århundredeskifte, stadig hjemsøger antropologien.

\section{Boas vs. Mason: opgøret med den typologiske udstillingsform}

I 1887 retter Boas en skarp kritik mod Masons måde at klassificere etnografiske objekter på. Kritikken er udformet som et debatindlæg i tidsskriftet Science, som Boas på daværende tidspunkt var redaktørassistent for, og den udvikler sig til en åben brevveksling mellem Boas og Mason (Boas 1887a, 1887b; Mason 1887). Mason kategoriserer etnografiske genstande på samme måde som biologisk 
materiale, det vil sige ud fra, hvilken familie, slægt og art, de menes at tilhøre. På 1880'ernes National Museum kunne man således finde en række typologisk organiserede montrer, som hver især indeholdt én bestemt slags genstande (fx jagtredskaber eller musikinstrumenter) fra hele verden, der var placeret efter, hvor teknologisk avancerede de var. Den typologiske udstillingsform er baseret på ,hypotesen om, at der eksisterer en forbindelse af en art mellem etnologiske fænomener hos vidt forskellige folk“" (Boas 1887a:485) ${ }^{1}$. Den forudsætter, at man ud fra nogle umiddelbart synlige lighedstræk mellem genstande fra forskellige samfund kan deducere sig frem til en generel udviklingsmæssig sammenhæng mellem disse samfund. Det vil sige, at man ved at sammenligne variationen af en bestemt genstandstype fra samfund til samfund kan sige noget om hvert af disse samfunds respektive teknologiske udviklingstrin og som følge deraf også, hvilket stadie de befinder sig på rent åndeligt. Mason giver også selv direkte udtryk for denne forståelse i en ikke nærmere specificeret tekst, som Boas citerer direkte fra: „I den menneskelige kultur, som i naturen i øvrigt, skaber lignende årsager lignende virkninger" (Mason citeret ibid.). Heroverfor fremsætter Boas omvendt den påstand, at „forskellige årsager skaber lignende virkninger“:

Det er meget sjældent, at forekomsten af lignende årsager til ens opfindelser kan bevises, idet de elementer, der påvirker det menneskelige sind, er så komplicerede og deres påvirkning så fuldkommen ukendt, at forsøget på at finde lignende årsager nødvendigvis må slå fejl eller forblive en vag hypotese. Tværtimod er udviklingen af lignende etnologiske fænomener af forskellige årsager langt mere sandsynlig og i overensstemmelse med de bagvedliggende årsagers kompleksitet (ibid).

Boas mener altså ikke, at forekomsten af den samme type genstand i forskellige samfund beviser, at de er historisk forbundne. Han påstår omvendt, at disse genstande er opstået i forskellige samfund uafhængigt af hinanden, og at deres typologiske lighed ikke bare er tilfældig, men også rent overfladisk. Studerer man genstandene nærmere, vil man ifølge Boas opdage, at de trods deres umiddelbare lighed er blevet anvendt $\mathrm{i}$ vidt forskellige sammenhænge og til vidt forskellige formål, alt efter hvilket samfund de optræder i. Et af Boas' eksempler er skralden, som genfindes i samfund verden over. Skralden er imidlertid „,ikke bare resultatet af ideen om at skabe larm og af de tekniske metoder, der anvendes for at nå dette mål“" (Boas 1887b:588). Den er også et produkt af den specifikke funktion, som den tillægges i det enkelte samfund, og som kan variere fra legetøj over musikinstrument til religiøst åndemaningsredskab (ibid.). Der er derfor ikke videnskabeligt belæg for at placere skralder fra forskellige steder i verden i samme kategori alene på grund af deres typologiske lighed. I artiklen „The Limitations of the Comparative Method of Anthropology“ fra 1896 udfolder Boas dette argument yderligere. Han tager udgangspunkt i det faktum, at ,i studiet af en 
hvilken som helst stammes kultur, vil denne kulturs enkelte træk kunne genfindes blandt mange forskellige folkeslag“ (Boas 1896:901). Hvor evolutionister som Mason ifølge Boas anser disse ligheder for at være „uigendriveligt bevis på en historisk forbindelse eller endda en fælles oprindelse“, fortolker Boas dem omvendt som „et resultat af menneskesindets ensartede måde at arbejde på“ (ibid.). Han mener med andre ord ikke, at lighederne beviser, at „,der har været nogen fælles historisk kilde, men at de er opstået uafhængigt" (ibid.). Denne tese underbygges efterfølgende med en lang række konkrete eksempler på universelt forekommende kulturelle fænomener, som han forsøger at påvise er opstået af vidt forskellige årsager.

For at forstå en bestemt menneskeskabt genstands funktion bør man ifølge Boas ikke sammenligne den med genstande af samme type fra andre samfund, men med andre typer genstande fra det samme samfund. Det er med andre ord ikke muligt at forstå genstanden løsrevet fra dens oprindelige kontekst: „Vi kan ikke forstå et enkelt redskab ved at anskue det uafhængigt af dets omgivelser, uafhængigt af andre opfindelser frembragt af det folkeslag, det tilhører, eller uafhængigt af andre fænomener, som berører dette folkeslag og dets produktion“" (Boas 1887a:485). Boas forskyder dermed fokus fra genstandenes form til deres betydning og slår samtidig fast, at denne betydning er determineret af det særlige kulturelle fællesskab, som genstanden er blevet skabt og anvendt i. Som en konsekvens heraf mener Boas også, at museerne bør arrangere deres etnografiske genstande ud fra, hvilket samfund de er produceret $i$, frem for hvilken universelt forekommende type de tilhører. Hvor den typologiske udstillingsform ifølge Boas er baseret på umiddelbart synlige, men overfladiske og tilfældige lighedstræk, er den udstillingsform, han plæderer for, omvendt baseret på en dybereliggende, men immateriel sammenhæng i form af det enkelte samfunds åndelige enhed. Boas vender således Masons forklaringsmodel på hovedet. Det er ikke længere studiet af materielle genstande, der danner baggrund for klassificeringen af de enkelte samfund, men tværtimod studiet af disse samfunds befolkning og deres adfærd, der danner baggrund for genstandenes klassificering. Derfor kan museets kuratorer ifølge Boas heller ikke nøjes med at udvikle abstrakte, spekulative teorier om eksistensen af nogle kulturhistoriske udviklingssammenhænge på tværs af forskellige samfund, men må ansætte et team af feltarbejdere, som kan akkumulere konkret, empirisk viden om det enkelte samfund og dets indre sammenhænge (Jacknis 1985:89).

Boas var selv en af de første antropologer, som engagerede sig i feltarbejde. Hvor størstedelen af hans samtidige kolleger nøjedes med at studere andre kulturer i rejselitteraturen og på museerne, drog Boas allerede så tidligt som i 1883 ud på sin første feltekspedition, som havde Baffin Island som destination. Han 
foretog desuden en række længerevarende feltstudier blandt nordamerikanske indianere op gennem 1880'erne og -90'erne og var under sin ansættelse på AMNH initiativtager til den såkaldte „Jesup North Pacific Expedition“, en videnskabelig feltekspedition, som fandt sted i perioden 1897-1902 med Boas som en af de ledende antropologer. Selvom flere af de ekspeditioner, som Boas deltog i, havde indsamlingen af etnografiske artefakter som erklæret mål, var de ikke desto mindre en af de vigtigste forudsætninger for Boas' gryende skepsis over for studiet af materielle genstande som kilde til viden om verdens kulturer. Boas' felterfaringer bidrog mere end noget andet til at åbne hans øjne for de mere uhåndgribelige, immaterielle aspekter af andre folkeslags levevis - for det, som Bronislaw Malinowski har kaldt for „hverdagslivets imponderabilier“ (Malinowski 1922:20).

Med sin påstand om, at „forskellige årsager skaber lignende virkninger“ anfægter Boas Masons grundlæggende tese om, at menneskehedens kulturelle udviklingshistorie skal forstås som et samlet, unilineært fremadskridende forløb, hvori verdens mange forskellige samfund repræsenterer hver deres stadie. Han mener i stedet, at de enkelte samfund er lige udviklede, men til gengæld har udviklet sig forskelligt og uafhængigt af hinanden, og at de derfor må forstås som sidestillede, selvstændige og samtidige kulturer. Det betyder, at det etnografiske museum ikke længere skal konsolidere det moderne Europas placering i toppen af det kulturhistoriske udviklingshierarki, men tværtimod bør udfordre klassiske eurocentriske dogmer:

Jeg er af den mening, at etnologiske samlingers hovedformål bør være at udbrede det faktum, at civilisation ikke er noget absolut, men at den er relativ, og at vore ideer og begreber kun er sande inden for vores egen civilisation. Jeg mener kun, at dette formål kan opfyldes gennem en stammebaseret organisering af samlingerne. Det andet formål, som er underordnet det første, er at vise, i hvor høj grad hver eneste civilisation er resultatet af dens geografiske og historiske omgivelser (Boas 1887b:589).

Boas lægger således op til, at det etnografiske museum ikke blot skal formidle viden om andre samfund, men også - og endog som det vigtigste - levere et kritisk relativerende blik på vores eget samfund og dets værdier.

\section{Boas vs. Dorsey: det etnografiske museums (u)mulighed}

I 1907, 20 år efter sin polemik med Mason, tager Boas igen diskussionen om det etnografiske museums udstillingspraksis op i en debat med George A. Dorsey, kurator ved Field Museum of Natural History i Chicago. I et nummer af Science fra april 1907 retter Dorsey en skarp kritik mod en række af AMNH's antropo- 
logiske udstillinger (Dorsey 1907). Tre måneder senere svarer Boas igen med artiklen „Some Principles of Museum Administration“ i samme tidsskrift (Boas 1907), hvor han forsvarer AMNH mod Dorseys beskyldninger. Hvor Boas optræder som anklager i diskussionen med Mason, indtager han forsvarerens rolle i diskussionen med Dorsey. Det er nu pludselig hans egen udstillingspraksis, der kommer under kritik. Men selvom formålet med Boas' artikel er at forsvare $\mathrm{AMNH}$, eksponerer artiklen ikke desto mindre en række generelle, iboende begrænsninger både specifikt ved den udstillingspraksis, som han selv har været med til at implementere, og mere generelt ved museet som moderne institution. Disse begrænsninger er netop en af de væsentligste årsager til, at Boas vælger at forlade museumsverdenen for altid i 1905, og i et bredere perspektiv også baggrunden for, at den videnskabelige antropologi i samme periode flytter fra museet til universitetet.

Dorseys kritik er ikke rettet mod AMNH's kulturelt kontekstualiserende udstillingsform, som han grundlæggende sympatiserer med, men snarere mod det faktum, at denne udstillingsform ikke er blevet tilstrækkeligt konsekvent implementeret på AMNH. Dorsey mener, at museet blot to-tre år tidligere havde „en af de bedste afdelinger for antropologi på noget museum i verden“ (Dorsey 1907:584). Det skyldtes både, at AMNH rummede samlinger fra langt flere kulturelle områder end de fleste andre museer, og at dets enkelte samlinger var langt mere omfattende. Det syntes ifølge Dorsey ,kun at være et spørgsmål om tid og videreførelse af den eksisterende politik, før alle kulturer, med undtagelse af dem i Europa, ville blive adækvat repræsenteret" på museet (ibid.). Samtidig blev genstandene udstillet på en sådan måde, at „man i afdelingens lokaler straks følte forskningens ånd, og det var overalt tydeligt, at dette var forårsaget af ønsket om at gøre videnskabelige fremskridt og ikke af ønsket om at finde materiale, der passede ind i eller harmonerede med en eller anden ideal plan for udstillingen" (ibid.).

Ifølge Dorsey var AMNH blot få år forinden det museum, der kom tættest på skabelsen af en videnskabelig totalvision, som repræsenterede verden i hele dens mangfoldighed. Men siden da er museets store, systematiske udstillinger, hvor flest mulige kulturer repræsenteres en efter en gennem flest mulige genstande, beklageligvis blevet erstattet af mindre udstillinger, der koncentrerer sig om nogle få udvalgte kulturer og repræsenterer disse gennem et mindre antal særligt iøjnefaldende genstande. Dorsey gennemgår tre forskellige etnografiske udstillinger på $\mathrm{AMNH}$ af sidstnævnte type, og hans konklusion er, at kuratorerne i forsøget på at gøre disse udstillinger så æstetisk appellerende som muligt giver et alt for unuanceret eller endda direkte misvisende billede af de pågældende kulturer. Om udstillingen, der tematiserer prærieindianernes levevis, skriver han eksempelvis: 
Gennem hele denne udstilling ser vi, ligesom i eskimoudstillingen, overalt resultatet af et bevidst forsøg på at få montrerne til at se pæne ud, på at få genstanden til højre til at harmonere i størrelse med genstanden til venstre, uanset om det illustrerer noget eller ej (op.cit.588).

Boas indleder sin artikel med at påpege, at Dorsey „forudsætter, at det store museums essentielle formål er forskning, ikke undervisning" (Boas 1907:921), hvilket Boas er grundlæggende uenig i. Selvom Boas i princippet fastholder, at det etnografiske museum både er en forsknings- og en formidlingsinstitution, mener han til forskel fra Dorsey, at sidstnævnte i praksis er det vigtigste. I resten af artiklen diskuterer Boas, hvori museets formidlingsmæssige opgave består, og hvilke udfordringer den indebærer. Han argumenterer samtidig indirekte for, hvorfor han mener, at museet er uegnet som centrum for forskning. Vi skal i det følgende se nærmere på disse to diskussioner, og vi begynder med den sidstnævnte.

\section{Forskningens (u)mulighed}

Hvor Dorsey favoriserer den store, systematiske udstilling, mener Boas omvendt, at „ethvert forsøg på at præsentere etnologiske data gennem en systematisk klassificering af genstandene ikke kun vil være kunstig, men også fuldstændigt vildledende“" (Boas ibid.). Det skyldes helt grundlæggende følgende:

Kulturernes psykologiske såvel som historiske relationer, som det er antropologiens eneste formål at undersøge, kan ikke udtrykkes gennem nogen form for udstilling baseret på så lille en del af det kulturelle livs manifestationer som den, der viser sig i genstandene (op.cit.928).

For det første peger Boas på, at museernes samlinger altid vil være „en ekstremt fragmenteret præsentation af et folks virkelige liv“ (ibid.), fordi de kun udgør et begrænset, mere eller mindre tilfældigt udsnit af den enkelte kulturs materielle produktion. For det andet fremhæver han samtidig, at der findes mange kulturelle praksisser, som slet ikke afsætter sig nogen materielle spor:

Det forekommer endda tit $i$ antropologiske samlinger, at et bredt spektrum af tanker kun udtrykkes i et enkelt objekt eller intet objekt overhovedet, fordi dette særlige aspekt af livet kun består af ideer. Hvis for eksempel én stamme bruger mange objekter i sin religiøse tilbedelse, mens der blandt andre stammer næsten ingen tilbedelsesobjekter bruges, så fremstår de sidstnævnte stammers religiøse liv, som kan være akkurat lige så levende, helt ude af deres rette proportioner i museumssamlingerne (ibid.). 
På den ene side er menneskeskabte artefakter ifølge Boas kun interessante, for så vidt de bidrager til en større videnskabelig forståelse af de kulturer, som de er blevet skabt og anvendt af. Det betyder, at det etnografiske museums primære forskningsobjekt ikke er de materielle genstande selv, men de immaterielle sociale praksisser, som de formodes at henvise til. Men på den anden side mener Boas ikke, at genstandene taler for sig selv, det vil sige, at man kan sige noget om de kulturer, der har produceret dem, alene ud fra deres overfladiske, immanente og umiddelbart synlige karakteristika. Han fremhæver, at „objekterne først og fremmest er tilfældige udtryk for de komplekse mentale processer, som i sig selv er genstand for antropologisk undersøgelse" (ibid.). Den moderne etnografiske udstillingsform, som Boas selv har været med til at opfinde, er således indfanget $i$ det dilemma, at dens væsentligste opgave er at forstå kulturerne via genstandene, samtidig med at den er baseret på en erkendelse af, at genstandene kun kan forstås ved at studere kulturerne. Det er netop dette dilemma, Boas eksponerer, når han kritiserer Dorseys idealisering af den store systematiske udstilling.

Den eneste måde, hvorpå man ifølge Boas kan omgå det skitserede dilemma, er ved at supplere genstandene med forskellige tekster, billeder og tredimensionelle modeller, der italesætter de usynlige, uudtalte træk ved de enkelte kulturer, som genstandene per definition selv må forblive tavse om. Denne tilgang implicerer imidlertid, at de etnografiske artefakter transformeres fra at være museets udstillingsobjekt par excellence til at være ét blandt flere sidestillede udstillingsobjekter - og fra at blive (re)præsenteret til selv at være en repræsentation. Det implicerer samtidig også, at museet ikke længere bliver et sted, hvor forskere kan studere andre kulturer, men snarere et sted, hvor de via forskellige medier kan formidle deres viden om disse kulturer til offentligheden.

\section{Formidlingens (u)mulighed}

Boas skelner indledningsvis i artiklen mellem to forskellige grupper af museumsgæster, hvis behov bør medtænkes i udformningen af museet: en lille minoritet, primært bestående af skoleklasser og deres lærere, som søger ,systematisk information“ (Boas 1907:925), og den store majoritet, som blot søger „sund underholdning“"(op.cit.922). Museet har således to grundlæggende formål, nemlig (ud)dannelse og underholdning (ibid.). I sin diskussion af, hvordan museet bedst opfylder disse to formål, er Boas' konklusion - ligesom i diskussionen af museet som forskningsinstitution - at den store, systematiske udstilling, som Dorsey plæderer for, er uegnet.

Når den store, systematiske udstilling ifølge Boas er et inadækvat redskab i en uddannelsesmæssig sammenhæng, hænger det sammen med, at der ikke 
blot findes én autoritativ måde at systematisere genstandene på, eller én autoritativ systematik, som kan inkludere alle genstande. Denne problematik er særligt fremtrædende på store museer som AMNH, hvis samlinger er utroligt diverse, og hvor besøgende skoleklasser søger information om alt fra zoologi og nervesystemets funktion til arternes udvikling og den lokale fauna (op.cit.926). Hvis alle disse behov skulle tilgodeses på et museum som AMNH, ville det indebære implementeringen af en lang række forskelligartede systematikker. Resultatet ville blive „sådan en labyrint af forskellige og gensidigt overlappende systemer, at den gennemsnitlige besøgende, selv hvis han er ivrig efter at få systematisk information, ville blive frustreret over mængden af præsenteret materiale“ (op.cit.925). Problemet er altså, at de enkelte systematikker gensidigt relativerer hinanden, hvilket stik imod intentionen gør, at museet - og dermed også den verden, det repræsenterer - ikke fremstår som en sammenhængende, harmonisk orden, men fragmenteret, uforståeligt og kaotisk. Det betyder samtidig, at museumsgæsternes opmærksomhed henledes på det faktum, at videnskabelige kategoriseringssystemer er kunstige, diskursive konstruktioner og ikke en objektiv repræsentation af verden. Boas mener, at problemet bedst løses, ved at der enten oprettes en særlig fløj af det store museum til uddannelse af børn og unge, eller at der etableres separate skolemuseer, som i kraft af deres mindre, mere specialiserede samlinger bedre kan retfærdiggøre kun at applicere én enkelt systematik. Dette løsningsforslag er dog en rent pragmatisk foranstaltning, som ikke ophæver modsigelserne mellem de enkelte systematikker, men blot gør dem mindre synlige for museumsgæsterne.

Hvor størstedelen af samtidens museer fokuserer på forskning og uddannelse, mener Boas omvendt, at museets vigtigste, men ofte oversete funktion er underholdning. Langt størstedelen af museets gæster „ønsker ikke andet end underholdning“" (op.cit.922):

De folk, der søger hvile og rekreation, hader at blive mødt af et forsøg på systematisk undervisning, når de søger følelsesmæssig spænding. De vil beundre, de vil imponeres af noget stort og vidunderligt, og hvis udstillingens underliggende idé fremhæves tilstrækkeligt tydeligt, kan de blive indpodet nogle store sandheder, uden at det på noget tidspunkt kræver nogen særlig indsats. Denne type besøgende går ikke på museum for at studere udstillingerne montre for montre eller følge den plan, kuratoren omhyggeligt har lagt. Han slentrer snarere gennem lokalerne og undersøger det, der tiltrækker hans opmærksomhed her og der, uden nogen plan eller noget mål (ibid.).

Boas er af den overbevisning, at man i stedet for at ignorere eller begræde dette faktum bør tage højde for det i museets indretning. Han diskuterer desuden indgående, hvordan museet bedst tilpasses behovet for underholdning uden at gå 
på kompromis med den videnskabelige redelighed. Her er en af hans pointer igen, at den store systematiske udstilling, som Dorsey plæderer for, er uegnet, fordi den med sine mange gentagelser (for eksempel montre efter montre med hundredvis af næsten ens flinteøkser) hurtigt kommer til at kede utålmodige, uskolede museumsgæster, der udelukkende søger „følelsesmæssig spænding“. Boas foreslår i stedet følgende alternativ:

For at tiltrække opmærksomhed fra de besøgende, der slentrer planløst gennem lokalerne, har museet brug for at skabe en lidt neutral baggrund af materiale, som her og der kan kontrasteres af en iøjnefaldende udstilling, der kan fange opmærksomheden: Museumsadministratorens kunst består i den rette udvælgelse af netop de udstillinger, der formår at tydeliggøre en bestemt idé. Et museum, der udelukkende består af en række iøjnefaldende udstillinger, modarbejder til en vis grad sine egne mål. For der hvor mange genstande af lige stor interesse er samlet på ét sted, vies den enkelte genstand kun ganske lidt opmærksomhed. Desuden kaster den neutrale baggrund, der består af udstillinger relateret til den iøjnefaldende udstilling, som illustrerer en specifik idé, lys over det givne problems vidtstrakte karakter og forhindrer en overfladisk antagelse om, at den ene iøjnefaldende udstilling udtømmer emnet (op.cit.923).

Det er bemærkelsesværdigt, at Boas her beskriver kuratering som en kunst. Denne opfattelse uddybes et andet sted i artiklen, hvor det hedder, at „det kræver det største talent at udvælge og iscenesætte en iøjnefaldende genstand, som klargør en vigtig idé som modvægt til en ensartet baggrund, således at det bedste resultat opnås“" (op.cit.924). Hvor Boas i polemikken mod Mason argumenterede for, at kuratorernes vigtigste opgave var at genskabe genstandenes oprindelige kulturelle sammenhæng så nøjagtigt som muligt, argumenterer han her for, at det er mindst lige så vigtigt at indsætte genstandene i en ny sammenhæng, der gør dem så emotionelt appellerende for museumsgæsterne som muligt. Kuratorens opgave er først og fremmest at skabe en række enkeltstående, iøjnefaldende installationer, som indledningsvis skal fange museumsgæsternes opmærksomhed. For når opmærksomheden først er fanget, er det langt nemmere at motivere museumsgæsterne til at se resten af udstillingen. Det er her, i den øvrige udstilling, at den kurateringsstrategi, som Boas plæderer for i diskussionen med Mason, gør sig gældende. Her får museumsgæsterne nemlig en mere dybdegående gennemgang af de enkelte kulturer en for en, hvor der er lagt mere vægt på videnskabelig præcision end på, hvad der forekommer mest emotionelt appellerende. Museets formål er i denne forståelse ikke kun at underholde sine gæster, men også at danne dem, men dannelsen tilvejebringes så at sige gennem underholdningen. Kuratorens fornemste opgave er at få museumsgæsterne til at omsætte deres umiddelbare fascination af nogle enkeltstående genstande til en mere generel viden om den kulturelle kontekst, som genstandene oprindeligt har indgået $i$. 


\section{Hall of Northwest Coast Indians}

En af de udstillinger, hvor det bedst lykkedes Boas at omsætte de pædagogiske principper, han beskriver i „Some Principles of Museum Administration“, i praksis, er AMNH's Hall of Northwest Coast Indians, som han forestod etableringen af fra 1901 og fremefter (Jacknis 1985:90). Samlingen fra den amerikanske nordvestkyst blev for første gang udstillet i 1896, samme år som Boas blev ansat ved AMNH, men fyldte på daværende tidspunkt kun halvdelen af lokalet, mens den anden halvdel husede samlinger fra det nordlige Canada, Mexico og Melanesien. Omkring 1901 flyttede de tre sidstnævnte samlinger over i museets nybyggede fløj, og samlingen fra den amerikanske nordvestkyst tildeltes hele lokalet. Det fremgår af AMNH's årsrapport for 1901, at denne omrokering skyldtes, at nordvestkystsamlingen i den pågældende periode blev udvidet med et stort antal nye genstande hjembragt fra den igangværende Jesup North Pacific Expedition (AMNH 1902:22-23). Det var Boas, der som ledende kurator for den etnografiske sektion af Afdelingen for Antropologi stod for omorganiseringen af den allerede etablerede samling fra den amerikanske nordvestkyst samt kategoriseringen af de nye genstande, som løbende blev integreret heri (Jacknis 1985:94).

1910'ernes Hall of Northwest Coast Indians er indrettet således, at der ned igennem rummets midte på langsiden er to parallelle rækker af glasmontrer med en smal gangpassage imellem og en bredere på hver sin side. På ydersiden af de to brede gangpassager er der placeret en række meterhøje, kvadratiske glasmontrer op mod væggene. Alle montrer er forsynet med numre, der indikerer, hvilken rækkefølge de skal ses i. Formålet med denne indretning er at lede museumsgæsterne gennem rummet ad en på forhånd fastlagt rute i stedet for blot at lade dem vandre omkring på må og få. Ved at etablere en række parallelle og relativt smalle gange i stedet for én bred passage ned gennem rummet har Boas forsøgt at undgå, at gæsterne krydser frem og tilbage over gulvet og dermed kun får set et lille, tilfældigt udsnit af samlingen (op.cit.93). I A General Guide to the American Museum of Natural History (Hovey 1904) findes der en detaljeret beskrivelse af de enkelte udstillingsmontrers indhold. Her fremgår det, at de tre første montrer, som museumsgæsterne passerer, rummer ,en generel eller synoptisk samling af genstande fra hele området, udformet for at illustrere folkeslagenes kultur som helhed“" (op.cit.41). Disse montrer er altså organiseret efter de forskellige delaspekter af nordvestkystindianernes kultur forstået som en helhed, for eksempel beklædning, håndværk og handel (op.cit.41f.). I de efterfølgende montrer finder vi omvendt ,adskillige uafhængige samlinger, der hver især illustrerer særegenheden ved den enkelte stammes kultur" (op.cit.41). Her præsenteres de enkelte samfund i samme rækkefølge, som de er lokaliseret i forhold til hinanden rent geografisk: Det nordligst beliggende samfund er placeret længst mod nord i lokalet, herefter 
følger nabosamfundet lidt længere mod syd osv. Udstillingslokalet bliver således en miniaturemodel over den region, det repræsenterer, og museumsgæsterne en art rejsende.

Det kan umiddelbart undre, at Boas ikke gør udstillingen gennemført kulturelt organiseret, men også benytter sig af et klassisk typologisk kategoriseringsprincip. Det er netop en af de anklager, som Dorsey retter mod AMNH. Forklaringen er, som Boas også indirekte redegør for i sit svar til Dorsey, at de formidlingsmæssige hensyn vejer tungere end hensynet til videnskabelig præcision. De typologisk organiserede montrer, der er strategisk placeret i begyndelsen af udstillingen, er specifikt møntet på den utålmodige museumsgæst, der ønsker et hurtigt overblik over det pågældende område som helhed og ikke er interesseret i forskellene de enkelte stammesamfund imellem (Jacknis 1985:93).

Overalt i udstillingslokalet forefindes der et righoldigt skriftligt og visuelt informationsmateriale i form af fotografier, tegninger, kort, skilte, tekstplancher, brochurer og endog hele videnskabelige monografier, der er hæftet fast på udstillingsmontrerne til ære for de særligt videbegærlige museumsgæster, som ønsker en mere dybdegående viden. Informationsmaterialet illustrerer, hvordan de udstillede genstande er blevet produceret og anvendt, men belyser også mere generelt de enkelte samfunds levevis, herunder også ,immaterielle“ aspekter såsom sprog. I hver sin ende af lokalet er der desuden placeret et diorama, der fungerer som blikfang, når museumsgæsterne træder ind i rummet. Det ene af disse dioramaer er en miniaturemodel af en typisk landsby. Det andet er en glasmontre indeholdende skiftende grupper af mannequindukker, der er iklædt traditionel klædedragt og opstillet, som om de er i færd med en eller anden dagligdags aktivitet.

\section{Dioramaet og den museale repræsentations begrænsninger}

Dioramaet er ifølge Boas en særdeles effektiv måde at formidle etnografisk viden på, idet det ikke kun appellerer til intellektet, men også til sanserne. Det er den af museets mange formidlingsformer, der så at sige bringer kulturerne tættest på museumsgæsterne, fordi det består af det, man inden for semiotikken kalder for henholdsvis ikonografiske og indeksikalske tegn. Semiotikeren Charles Sanders Peirce skelner mellem tre typer tegn: tegn, som har en arbitrær, konventionelt bestemt relation til det, de betegner, tegn, som har en lighedsforbindelse med det, de betegner, og tegn, som har en nærhedsforbindelse med det, de betegner. Disse tre typer tegn kaldes for henholdvis symbolske, ikonografiske og indeksikalske (Peirce 2011:104-15). Hvor museets skriftlige materiale (videnskabelige monografier, brochurer og plancher) består af symbolske tegn, består dets billedmedier (kort, tegninger og fotografier) overvejende af ikonografiske tegn. Dioramaet kan der- 
imod siges at være en kombination af ikonografiske og indeksikalske tegn. Det er en simulation af en bestemt dagligdags aktivitet, der skal illustrere, hvordan de udstillede genstande oprindeligt er blevet produceret og anvendt. Denne simulation er mere effektfuld end udstillingens øvrige ikonografiske medier, fordi der ikke blot er tale om en todimensionel gengivelse en miniature, men en tredimensionel 1:1-model. Samtidig har dioramaet også en konkret, nærhedsbaseret relation til den virkelighed, det henviser til: Mannequindukkerne er modelleret direkte efter kropsafstøbninger af indfødte, og de genstande, der indgår i dioramaet, er blevet skabt af det folk, som disse dukker repræsenterer. Hvor udstillingens tekst- og billedmateriale repræsenterer en i sig selv fraværende (kulturel) virkelighed, forsøger dioramaet helt konkret at gøre denne virkelighed nærværende. Det har nogle helt særlige taktile kvaliteter, som gør, at det i højere grad end museets tekst- og skriftmateriale appellerer til museumsgængernes forestillingsevne. Dioramaet får ideelt set museumsgængerne til at føle, at de - ligesom dem, der har indsamlet museets genstande - befinder sig i en anden verden, hvor de oplever andre kulturers levevis på allernærmeste hold.

Der er imidlertid en række praktiske problemer forbundet med at skabe de rette rammer for en sådan indlevelse. For det første bryder dioramaets omgivelser uundgåeligt den illusion, det forsøger at skabe. Det er ikke mindst et problem på et museum som AMNH, der er lokaliseret $i$ en bygning fra sidste halvdel af 1800tallet, hvor de mange søjler, mønstrede marmorgulve og dekorerede stuklofter konkurrerer med de udstillede genstande om museumsgæsternes opmærksomhed. Boas gør allerede opmærksom på dette problem i 1896, hvor han den 11. juli skriver følgende i et brev til Putnam:

Det er en stor gruppe mannequindukkers erklærede mål at hensætte den besøgende i fremmede omgivelser. Han skal se hele landsbyen og den måde, folk lever på, for sig. Men alle de forsøg på et sådant forehavende, jeg har set, har fejlet, fordi omgivelserne på et museum ikke er gunstige for at skabe et indtryk af denne type. Montrerne, væggene, indholdet af de andre montrer, søjlerne, trapperne, det minder os alt sammen om, at vi ikke kigger på en virkelig landsby, og kontrasten mellem gruppens tilstræbte realisme og de upassende omgivelser ødelægger hele effekten (Boas citeret i Jacknis 1985:101, kursivering i originalen).

For det andet er det vanskeligt at opnå en tilstrækkelig grad af realisme i udformningen af dioramaerne. Som Ira Jacknis har dokumenteret, gik Boas højt op i, at mannequindukkerne blev udformet så naturtro som overhovedet muligt, og han havde en professionel skulptør ansat til at varetage denne opgave, mens han arbejdede som kurator på AMNH (op.cit.98-99). Men samtidig må Boas sande, at mannequindukkerne er og bliver en bleg afskygning af de mennesker, de repræsenterer: „Ingen figur vil nogensinde ligne mennesket selv, uanset hvor 
godt den er lavet. Om ikke andet vil selve manglen på bevægelse afsløre, at der er tale om et forsøg på at kopiere naturen, ikke naturen selv“" (Boas citeret i Jacknis 1985:102). I stedet for at forsøge at camouflere mannequindukkernes kunstighed mener han derfor, at kuratorerne lige så godt kan gøre eksplicit opmærksom på den - for eksempel ved altid at male deres frisure i stedet for at påsætte rigtigt menneskehår (ibid.). For som han skriver i det føromtalte brev til Putnam: „Eftersom der er en skillelinje mellem natur og plastisk kunst, er det bedre at drage denne linje bevidst end at forsøge at skjule den“" (ibid.).

Boas tager denne diskussion op igen i debatten med Dorsey, hvor han argumenterer for, at et alt for virkelighedstro diorama er lige så uhensigtsmæssigt som et dårligt konstrueret et af slagsen:

Når iøjnefaldende udstillingers tekniske perfektion er meget stor, er der en allestedsnærværende fare for, at den beundrende offentlighed ikke ser den idé, udstillingen skal tilvejebringe, men helt glemmer at kigge på selve udstillingen i sin beundring af den tekniske dygtighed, der eksponeres i installationen. I en udstilling af måger, der svæver over havets bølger, er det for eksempel kun alt for sandsynligt, at de besøgende vil spørge 'Hvordan er de hængt op?', og når de kommer hjem fra museet, vil de fortælle deres venner om den usynlige ophængning af fuglene, men de vil formodentlig ikke vide, hvilken slags fugle det var (Boas 1907:923).

Det vellykkede diorama har samme problem som det mindre vellykkede, nemlig at museumsgæsternes opmærksomhed uvægerligt henledes på dioramaet selv som repræsentationsform, på kurateringens egen artfulness. Dioramaet bliver ikke blot et transparent medie til formidling af viden om andre kulturer, men også i sig selv et objekt for undren på lige fod med disse kulturer. I stedet for kun at illustrere, hvordan andre kulturer har produceret de udstillede genstande, kommer dioramaet også til at pege tilbage mod sine egne produktionsbetingelser. Det bliver i lige så høj grad et indeksikalsk tegn for kuratorernes håndværksmæssige kunnen som for kulturernes ditto. Der sker således en form for omvending, hvor det ikke kun som intenderet er det fremmede, der kommer til at fremstå hjemligt, men også det hjemlige, der pludselig fremstår fremmed. Konsekvensen af, at dioramaet selv træder i forgrunden som objekt, er, at de kulturer, det repræsenterer, træder i baggrunden. Uanset hvor realistisk dioramaet er, vil det altid allerede optræde i en ramme (i form af museet selv), som uundgåeligt punkterer dets illusion. Dioramaets forsøg på at gøre de udstillede genstandes kulturelle kontekst nærværende henleder ironisk nok netop opmærksomheden på denne konteksts fravær.

Som allerede antydet er der ikke blot tale om en rent formidlingsmæssig vanskelighed, som kan løses på et praktisk plan. Der er snarere tale om et langt mere fundamentalt, principielt problem, som er indbygget i selve den moderne 
etnografiske udstillingsforms teoretiske grundlag og derfor ikke kan overvindes inden for dens egne rammer. For det paradigmeskift inden for den etnografiske udstillingspraksis, som Boas er med til at tilvejebringe, medfører ikke alene etableringen af en kulturelt kontekstualiserende tilgang. Det implicerer også en grundlæggende skepsis over for, om kulturer kan repræsenteres via deres materielle frembringelser, og om det overhovedet er muligt at repræsentere kulturer i museets regi. Der eksisterer med andre ord en uovervindelig kløft mellem Boas' ideal om at præsentere genstandene i deres kulturelle kontekst og museets per definition dekontekstualiserende tilgang, som består i at isolere genstandene fra deres oprindelige kulturelle, fysisk-konkrete sammenhæng for at indsætte dem i en ny i form af den etnografiske udstilling.

Det er netop i erkendelse af disse begrænsninger, at Boas i 1905 vælger at forlade museumsverdenen for altid til fordel for den karriere inden for universitetsverdenen, som senere skulle sikre ham en international status som den moderne antropologis fader. Det er samtidig disse begrænsninger, der er baggrunden for, at den videnskabelige antropologi mellem 1890 og 1920 flytter fra museet til universitetet og samtidig erstatter de spekulative, makrohistoriske teorier baseret på studier af materielle genstande med empiriske feltstudier baseret på førstehåndsobservationer af en specifik befolkningsgruppes sociale adfærd.

\section{Relativismens radikalisering}

I diskussionen med både Mason og Dorsey kredser Boas om et helt centralt spørgsmål, nemlig om det overhovedet er muligt at repræsentere et folk og dets levevis via de materielle genstande, de har produceret, og i så fald hvordan. Til grund for dette spørgsmål ligger to hovedantagelser, som er blevet anfægtet fra forskellige sider inden for nyere antropologi, nemlig at der eksisterer et apriorisk skel mellem sand og falsk etnografisk repræsentation, og at der eksisterer et apriorisk skel mellem materiel og immateriel kultur. Begge disse antagelser forudsætter samtidig, at sproget og verden opfattes som to adskilte størrelser.

Et paradigmatisk eksempel på en kritik af forestillingen om et apriorisk skel mellem sande og falske repræsentationer finder vi i Writing Culture: The Poetics and Politics of Ethnography fra 1986, som er redigeret af James Clifford og George Marcus. Denne antologi, som er et af de tidligste og mest programmatiske eksempler på den „retoriske vending“ i antropologien i 1980'erne, består af en række artikler, der på selvrefleksiv vis retter et kritisk fokus mod antropologien selv og dens mest kanoniske værker. Forfatternes grundlæggende antagelse er, som Clifford skriver i forordet, at den etnografiske monografi ikke som konventionelt antaget er en transparent, objektiv, empirisk funderet repræ- 
sentationsform, men tværtimod en retorisk konstruktion, som deler mange lighedstræk med skønlitteraturen (Clifford \& Marcus 1986:2). Flere af antologiens artikler demonstrerer, hvordan kanoniserede etnografiske værker benytter sig af litterære virkemidler som for eksempel metaforisk sprog, narrative strukturer og dramatiseret dialog. Mens den litterære retorik i disse værkers egen selvforståelse fungerer ,som ren dekoration eller blot som en måde at repræsentere en objektiv analyse eller beskrivelse mere effektivt på“ (op.cit.4), er denne retorik ifølge forfatterne konstituerende for selve værkets indhold. De mener, at form og indhold er gensidigt betingede, uadskillelige størrelser, og at den måde, som en bestemt kultur beskrives på, nødvendigvis er bestemmende for, hvad der siges om den. Formålet med at fremhæve de etnografiske monografiers litterære karakter er imidlertid ikke at klandre dem for manglende objektivitet. Det er snarere at nedbryde selve det skel mellem subjektiv og objektiv, faktuel og fiktiv samt retorisk og referentiel, som disse monografier er baseret på, til fordel for forestillingen om al repræsentations performativitet. Tesen er, at den materielle verden altid allerede er tekstliggjort. Hvor Boas forsøgte at redde den etnografiske repræsentations objektivitet ved at forflytte den fra udstillingen til bogen, afslører skribenterne i Writing Culture dette redningsprojekts illusoriske karakter.

For at finde en egentlig kritik af Boas' forestilling om et apriorisk skel mellem materiel og immateriel kultur skal vi helt frem til den „ontologiske vending“ i antropologien i 2000'erne. Et eksempel på dette er antologien Thinking Through Things: Theorising Artefacts Ethnographically fra 2007, der er redigeret af Amiria Henare, Martin Holbraad og Sari Wastell. I bogens forord polemiserer de tre redaktører imod den gængse forestilling om, at „,betydninger kun kan forstås som abstraktioner - ideer, der på en eller anden måde cirkulerer i æteren oven over et materielt grundlag, der i sig selv er blottet for betydning" (Henare et al. 2007:3). De plæderer i stedet for ,at ting skal behandles som sui generis betydninger" (ibid., kursivering i originalen). Det vil sige, at betydning ikke er noget udefrakommende eller forudgående i forhold til tingene, men at tingene derimod selv er betydningsskabende. Ting er i denne forståelse aldrig blot passive eller neutrale, men besidder en form for agens på linje med mennesket. Det er ikke kun menneskene, der bestemmer tingenes betydning. Tingene virker også tilbage på menneskene og får dem til at handle på en bestemt måde - nøjagtig ligesom diskurser. Pointen hos Henare, Holbraad og Wastell er netop, at den konventionelle skelnen mellem tegn og betegnet, mellem sprog og verden og mellem kultur og natur i sig selv er en sproglig konstruktion, hvis forekomst er begrænset til vores egen (vestlige) kultur og derfor ikke er et adækvat redskab, når det gælder beskrivelsen af andre (ikke-vestlige) kulturer (op.cit.4). De ønsker i det hele taget at forkaste det forudindtagede teoretiske begrebsapparat, som 
antropologer konventionelt gør brug af, når de skal analysere de indsamlede data fra felten, fordi det indstifter en unødig distance mellem antropologerne selv og deres studieobjekt:

I stedet for at bibringe data, som teorien kan appliceres på, og som kan afsløre en eksisterende teoretisk models styrker og svagheder, får de ting, man møder gennem feltarbejdet, lov til at diktere betingelserne for deres egen analyse - inklusive helt nye præmisser for teori (ibid.).

Fokuseringen på materielle genstande er således ikke et forsøg på at erstatte feltstudiet, som Boas bidrog til at gøre til antropologens arbejdsform par excellence, med en museumsbaseret „lænestolsantropologi“ a la den, vi finder hos Mason. Det er tværtimod et forsøg på at opvurdere feltstudiet, at give det en endnu mere central plads i antropologisk forskning, end det hidtil har haft. Henare, Holbraad og Wastell mener nemlig, at antropologerne bør nedbryde den klassiske adskillelse mellem de erfaringer, de gør sig i felten, og deres efterfølgende analyse, $\mathrm{i}$ erkendelsen af at deres møde med genstandene i felten altid allerede er et møde med betydninger og ikke blot en simpel dataindsamling (op.cit.4). Antropologens opgave er i denne forståelse ikke at bruge empirien som redskab til at (videre)udvikle allerede eksisterende (vestlige) teorier, men snarere at lade nye teorier udspringe af empirien selv. Hvor antropologerne konventionelt har forsøgt at udrede, hvorfor bestemte kulturelle fænomener er opstået med udgangspunkt $\mathrm{i}$ eksempelvis en funktionalistisk, marxistisk eller strukturalistisk forklaringsmodel, ønsker Henare, Holbraad og Wastell omvendt at tage disse fænomener på ordet, at begrebsliggøre dem på baggrund af de præmisser, de selv tilbyder (op.cit.8). Og hvor antropologerne hidtil har forudsat, at der findes en række forskellige, men sidestillede måder at opfatte verden på, mener antologiens tre redaktører omvendt, at der slet og ret findes en række forskellige, sidestillede verdener. Henare, Holbraad og Wastell forsøger dermed at vige uden om den traditionelle differentiering mellem forskellige verdensopfattelser på den ene side og verden, som den virkelig er, på den anden; en differentiering, som uundgåeligt placerer antropologerne i en privilegeret, bedrevidende position i forhold til de folk, de studerer.

Selvom forfatterne til Thinking Through Things gør op med Boas' distinktion mellem materiel og immateriel kultur, er det underliggende formål med deres „ontologiske vending“ (op.cit.12) imidlertid det samme som Boas’ formål med sine museumskritiske artikler omkring forrige århundredeskifte, nemlig at komme antropologiens indbyggede eurocentrisme til livs. Henare, Holbraad og Wastell er i lige så høj grad som Boas på vagt over for enhver form for interkulturel komparatisme, fordi de ligesom han mener, at den uundgåeligt resul- 
terer i oprettelsen af et implicit hierarki, et hierarki, hvor den vestlige kultur, som antropologen selv tilhører, kommer til at rangere over de kulturer, som antropologen studerer. Men hvor Boas i sidste ende anså studiet af materielle genstande - og dermed museet som institution - for at være uforeneligt med en kulturrelativistisk tænkning, forsøger Henare, Holbraad og Wastell omvendt at radikalisere kulturrelativismen ved at genindsætte materielle genstande i centrum af det antropologiske studie.

Denne radikalisering af den boasianske relativisme genfindes også i Writing Culture, om end i en lidt anden version. For hvor forfatterne til Thinking Through Things nedbryder den konventionelle dikotomi mellem sprog og verden ved at reducere alt til at være ting (i verden), nedbryder forfatterne til Writing Culture omvendt denne dikotomi ved at reducere alt til at være sprog - eller i bredere forstand repræsentation. ${ }^{2}$ Forfatterne til Writing Culture radikaliserer den boasianske relativisme ved at udfordre selve forestillingen om objektiv etnografisk repræsentation. De opgiver studiet af andre kulturer til fordel for studiet af deres egen videnskab. De vender på kritisk vis blikket indad for dermed at eksponere antropologiens egen relativitet. I Thinking Through Things fastholder forfatterne omvendt tilliden til, at man som (vestlig) antropolog kan repræsentere andre (ikkevestlige) kulturer på objektiv vis, men omdefinerer til gengæld kriterierne for, hvad objektiv repræsentation vil sige. Det drejer sig i deres forståelse ikke om at objektivere kulturerne, men om at gøre sig til objekt for deres indflydelse - at se dem indefra med de indfødtes egne øjne frem for at anlægge et udefra beskuende perspektiv. Hvor forfatterne til Writing Culture insisterer på den etnografiske repræsentations performativt skabende karakter, insisterer forfatterne til Thinking Through Things omvendt på de etnografiske objekters - det vil sige tingenes performativt skabende karakter, deres evne til at virke meningsskabende tilbage på deres omgivelser, inklusive antropologen på feltarbejde.

Når det er interessant at kaste et historisk tilbageblik på Boas' museumsfaglige debat med henholdsvis Mason og Dorsey, er det således ikke kun, fordi antropologer i dag i stigende grad problematiserer de synspunkter, som Boas fremsatte i disse debatter - og som i høj grad har været konstituerende for den moderne antropologi som sådan. Det er også, fordi Boas er en af de første antropologer, som stiller spørgsmålstegn ved den etnografiske repræsentations mulighedsbetingelser og formulerer eurocentrismen som et problem. Den kulturrelativistiske tænkning, som Boas lancerede omkring forrige århundredeskifte, lever stadig videre i bedste velgående inden for antropologien i dag, men blot i nye, mere radikaliserede former, som får Boas' egen løsning på eurocentrismens problem til at fremstå som en fordobling af denne eurocentrisme. Det er Writing Culture og Thinking Through Things begge fremragende eksempler på. Men som selve diskrepansen mellem 
disse to antologiers perspektiver med al tydelighed viser, er det stadig et åbent spørgsmål, hvordan det er muligt at overvinde den forblindende eurocentrisme, som forfatterne til de to antologier nøjagtig ligesom Boas mener, til stadighed hjemsøger antropologien.

\section{Noter}

1. Samtlige citater er oversat til dansk af forfatteren.

2. Det er dog vigtigt at understrege, at forfatterne til Thinking Through Things arbejder med et udvidet tingsbegreb, der ikke kun omfatter materielle genstande i snæver forstand. Henare, Holbraad og Wastell argumenterer i bogens introduktion for, at „ting“ skal forstås heuristisk frem for analytisk (Henare et al. 2007:5-7). Forfatterne til Writing Culture arbejder parallelt hermed med et udvidet tekstbegreb, der ikke kun omfatter skriftlige dokumenter, men alle former for semiotiske tegn.

\section{Søgeord: Franz Boas, det etnografiske museum, kulturrelativisme, materiel kultur,} den ontologiske vending, den retoriske vending

\section{Litteratur}

American Museum of Natural History

$1902 \quad$ Annual Report of the President, Treasures Report, List of Accessions, Acts of Incorporation, Constitution, By-laws and List of Members for the Year 1901. New York: American Museum of Natural History.

Boas, Franz

1887a The Occurrence of Similar Inventions in Areas Widely Apart. Science 9(224): 485-6.

1887b Museums of Ethnology and Their Classification. Science 9(228):587-9.

1896 The Limitations of the Comparative Method of Anthropology. Science 4(103): 901-08.

1907 Some Principles of Museum Administration. Science 25(650):921-33.

Clifford, James \& George E. Marcus (eds.)

$1986 \quad$ Writing Culture: The Poetics and Politics of Ethnography. Berkeley \& Los Angeles; London: University of California Press.

Dorsey, George A.

1907 The Anthropological Exhibits at the American Museum of Natural History. Science 25(641):584-9.

Henare, Amiria, Martin Holbraad \& Sari Wastell

2007 Introduction: Thinking Through Things. In: A. Henare, M. Holbraad \& S. Wastell (eds.): Thinking Through Things. Theorising Artefacts Ethnographically. Pp. 1-31. New York: Routledge.

Hovey, O. E.

1904 A General Guide to the American Museum of Natural History. Guide Leaflet 13. New York: American Museum of Natural History. 
Jacknis, Ira

1985 Franz Boas and Exhibits: On the Limitations of the Museum Method of Anthropology. In: G.W. Stocking (ed.): Objects and Others: Essays on Museums and Material Culture. Pp. 75-111. Madison: University of Wisconsin Press.

Malinowski, Bronislaw

1922 Argonauts of the Western Pacific: An Account of Native Enterprise and Adventure in the Archipelagos of Melanesian New Guinea.

London: George Routledge \& Sons.

Mason, O. T.

1887 The Occurrence of Similar Inventions in Areas Widely Apart. Science 9(226): 534-5.

Peirce, Charles S.

2011 Logic as Semiotic: The Theory of Signs. In: J. Buchler (ed.): Philosophical Writings of Peirce. Pp. 98-119. New York: Courier Dover Publications.

Sturtevant, William C.

1969 Does Anthropology Need Museums? Proceedings of the Biological Society of Washington 82:619-50. 
